\title{
Ultrastructural study on tissue alterations caused by trypanosomatids in experimental murine infections
}

\author{
Héctor J. Finol * and Antonio Roschman-González \\ Center for Electron Microscopy, Faculty of Sciences, Central University of Venezuela, Caracas, Venezuela
}

Edited by:

Rubén Bueno-Mari, University of

Valencia, Spain

\section{Reviewed by:}

Charles E. White, Charles E. White's

Biostatistical Consulting, LLC, USA

Hyacinth Idu Hyacinth, Medical

University of South Carolina, USA

\section{*Correspondence:}

Héctor J. Finol, Center for Electron

Microscopy, Faculty of Sciences,

Central University of Venezuela,

Apartado 40.494, Los Chaguaramos,

Caracas 1041A, Venezuela

e-mail: hector.finol@gmail.com
The ultrastructural study in different tissues of mice experimentally infected with isolates of Trypanosoma evansi, Trypanosoma cruzi, and Leishmania mexicana reveals changes in cardiac myocytes, skeletal muscle fibers, and hepatic, adrenal, kidney, and spleen cells. Some of these changes were cytoarchitectural and others consisted of necrosis. Alterations in the microvasculature were also found. The mononuclear cell infiltrate included neutrophils, eosinophils, and macrophages. This work shows that diverse mice tissues are important target for trypanosomatids.

\section{Keywords: pathology, ultrastructure, murine tissues, experimental infections, trypanosomatids}

\section{INTRODUCTION}

At the present time, there is a vast literature concerning the effects of protozoan parasites in the ultrastructure of mammalian tissues. These works include horse and mouse skeletal muscles infected by Trypanosoma evansi $(1,2)$ and Toxoplasma gondii $(3,4)$, human skeletal and mouse cardiac muscles by Trypanosoma cruzi $(5,6)$, avian skeletal muscle by Plasmodium cathemerium (7), and human skeletal muscle by Plasmodium falciparum (8). Alterations in the mouse adrenal gland and liver were provoked by Trypanosoma evansi $(9,10)$ and Plasmodium berghei $(11,12)$. In this context, it would be interesting to know if structural changes observed are similar in all studied species. Furthermore, with this investigation we intend to perform a systematic work on the ultrastructure of alterations in experimental murine infections by some trypanosomatids. This could help to understand better the biology of trypanosomatids in vertebrate host.

\section{MATERIALS AND METHODS EXPERIMENTAL INFECTIONS}

For experimental infections, Balb/c mice were used. They were divided into 3 groups of 10 mice each one for the three used species (Trypanosoma cruzi, Trypanosoma evansi, and Leishmania mexicana), and one additional 10-mice group was used as a control. Animals were infected by intraperitoneal (i.p.) route with inocula consisting of 10 parasites/g of animal body weight and uninfected mice were kept as controls. Three mice from each group were randomly selected after prepatent period and killed under anesthesia during peaks of infection. Then tissue samples were removed and processed for transmission electron microscopy. The experimental procedures were approved by the ethical committee of the Sciences Faculty at the Central University of Venezuela, and the work was conducted in agreement with the regulatory standards.

\section{TRANSMISSION ELECTRON MICROSCOPIC STUDY}

Tissue samples were fixed with Karnovsky's solution, in phosphate buffer at $\mathrm{pH} 7.4$ and $320 \mathrm{mOsm}$, post-fixed in $1 \% \mathrm{O}_{\mathrm{s}} \mathrm{O}_{4}$, and embedded in epon resin. Sections were cut with a diamond knife in a Porter-Blum MT-2B ultramicrotome and stained with uranyl acetate and lead citrate. Ultrathin sections were observed in a Jeol JEM - 1011 transmission electron microscope, at an accelerating voltage of $80 \mathrm{kV}$.

\section{RESULTS}

Pathological reactions in experimentally infected mice with diverse trypanosomatids showed some common characteristics in studied tissues of different replicates for each experimental group. Cardiac myocytes in T. evansi (Figure 1A) and skeletal muscle fibers in $T$. evansi and L. mexicana (Figure 1B) parasitized animals exhibited atrophy. In cardiac myocyte sections, myofibrillar disorganization and myofilament loss were seen (Figure 1A). Skeletal muscle fibers from mice infected with $T$. evansi showed segmental necrosis. In these areas (Figure 1C), mitochondrial paracrystalline debris was located next to contractile masses. As it is showed in Figure 2A, in T. cruzi similarly to the case of infection with T. evansi, liver hepatocytes showed an increment of lipid droplets, depletion in glycogen content, and decrease of microvilli in Disse's space. Sinusoid endothelial cells were widened with scarce pinocytotic vesicles. Hepatocyte debris was observed in some sinusoids, suggesting parenchymatous cell necrosis (Figure 2B). In mice infected by different trypanosomatids, adrenal cortical cells alterations were represented by lack of cytoarchitectural relations between mitochondria and smooth endoplasmic reticulum (SER), swelling of SER elements, decrease of mitochondrial cristae, widened nuclear envelop, change of electron density in cell cytoplasm, and presence of lysosomes (Figures 3A,B). Intracellular erythrocytes were observed in the infection with T. cruzi (Figure 3B), while T. evansi 

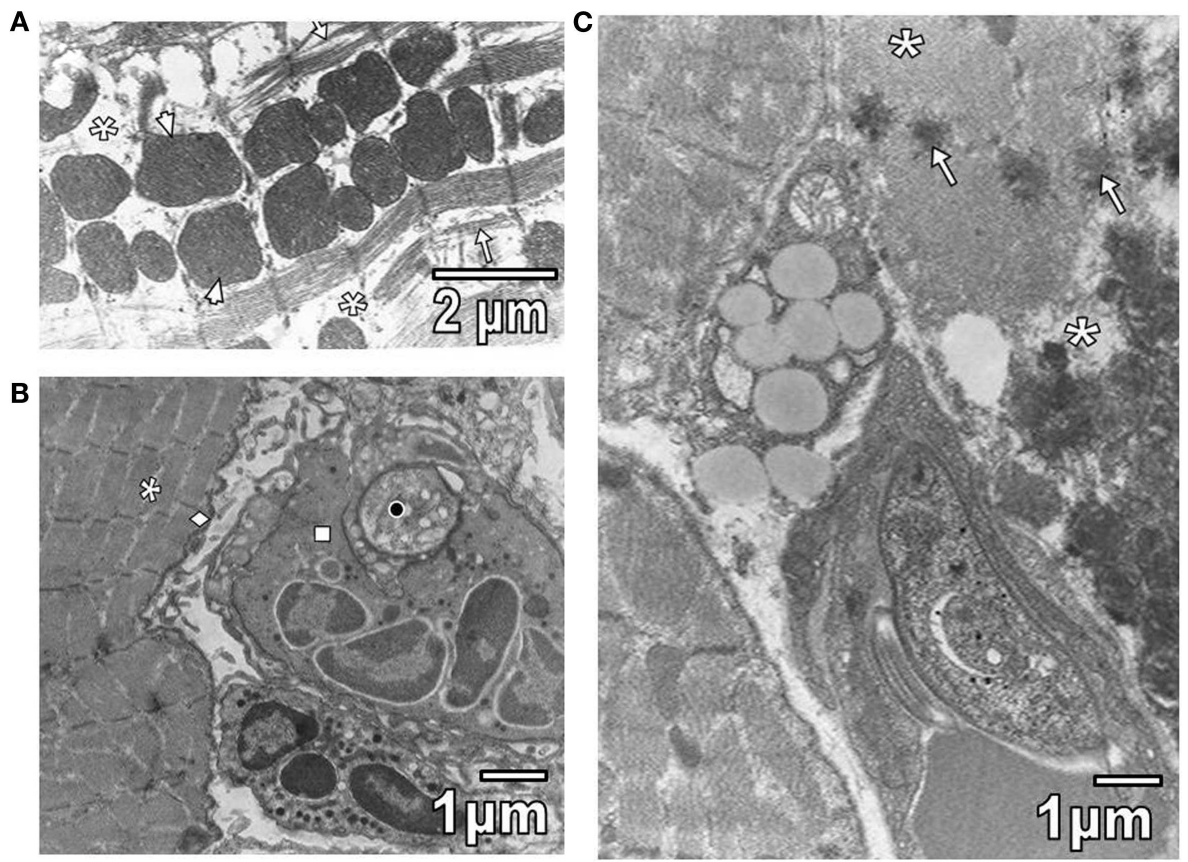

FIGURE 1 | (A) This section shows widened intermyofibrillar spaces (asterisks) of cardiac myocytes in T. evansi extensively occupied by mitochondria (arrowheads) and disorganized sarcomeres (star).

(B) Section of skeletal muscle from a mouse parasitized with

L. mexicana is shown. Intermyofibrillar (asterisk) and subsarcolemmal (rhombus) spaces are slightly widened. Observe a parasite (black circle) inside of neutrophil (square). (C) Section of skeletal muscle from a mouse parasitized by T. evansi is shown. Note areas of segmental necrosis (asterisks) showing mitochondrial debris with paracrystalline inclusions (arrows).
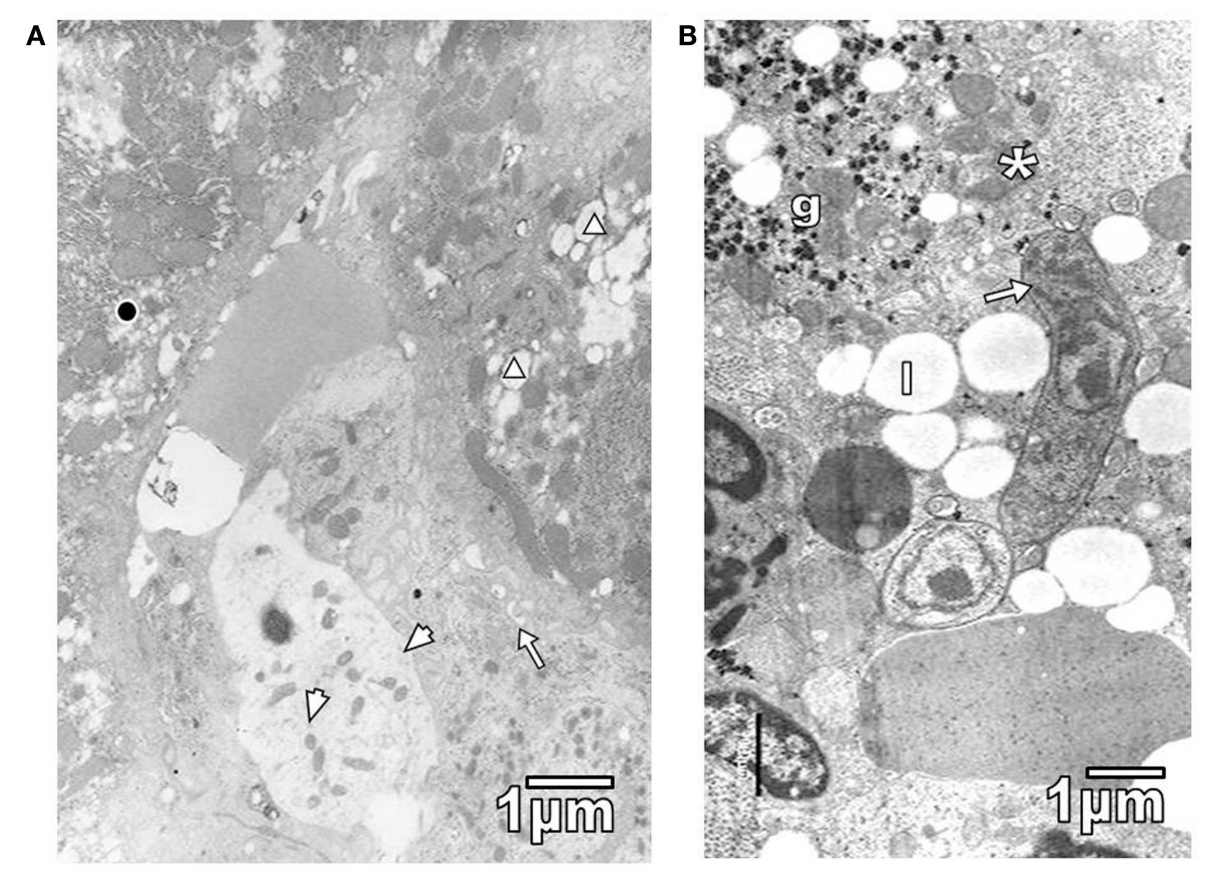

FIGURE 2 | (A) Section of hepatic parenchymatous cells from a mouse parasitized with T. cruzi is shown. Observe lipid droplets (triangle), glycogen depleted areas (black circle), some microvilli in Disse space (arrow), and widened sinusoid endothelial cells with few pinocytic vesicles (arrowheads). (B) Sinusoid lumen showing T. evansi parasite (arrow) and hepatocyte debris, including glycogen particles (g), mitochondria (asterisk), and lipid droplets (I). 

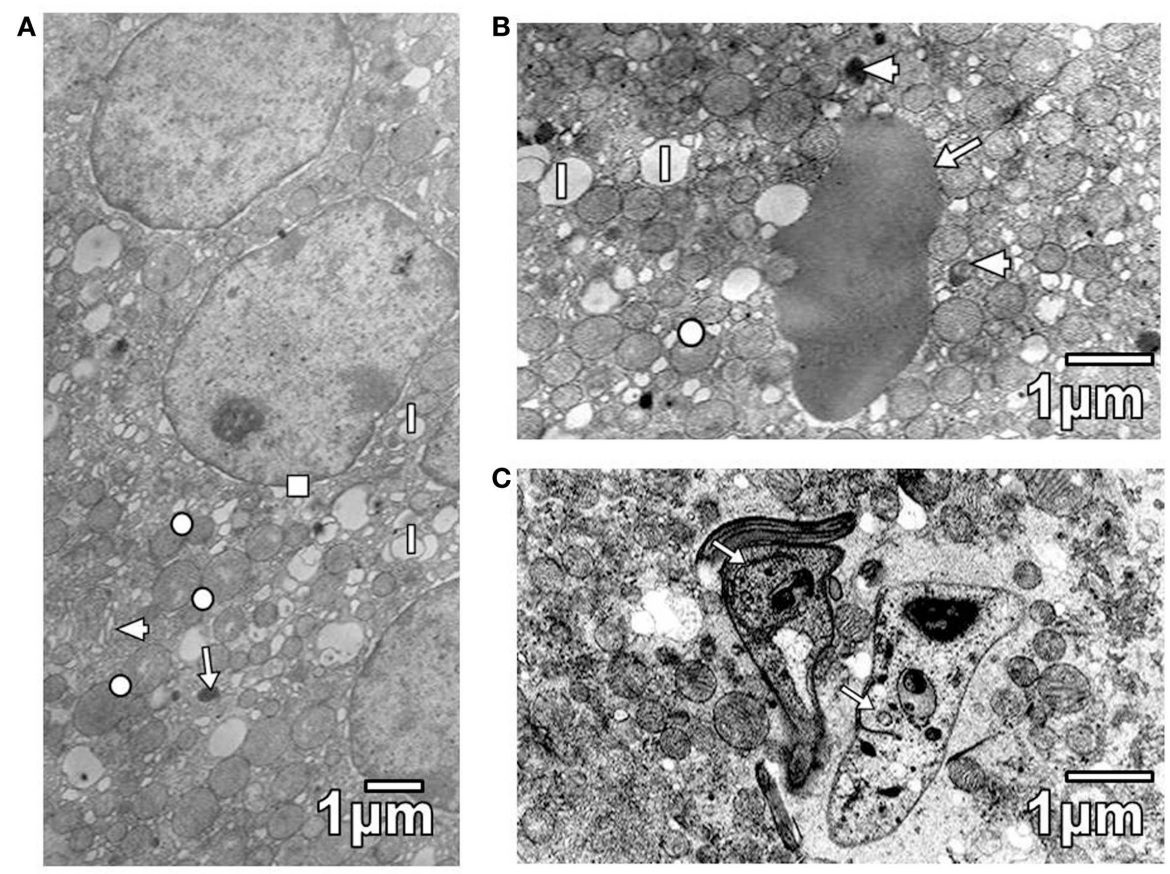

FIGURE 3 | (A) Section of cortical cells shows swollen elements of SER (arrowhead), some mitochondria with decreased cristae (circle), lipid droplets (I), lysosomes (arrow), and a widened nuclear envelop (square). (B) Section of a cortical cell from $T$. cruzi parasitized mouse, showing mitochondria with variable number of cristae (circle), lipid droplets (I), and lysosomes (arrowheads). Note the presence of an erythrocyte (arrow). (C) Section of a cortical cell from a mouse parasitized with T. evansi is shown. Observe the presence of parasites (arrows). parasites were seen in cortical cells of parasitized mice (Figure 3C). Additionally, capillary fenestrae were widened.

Kidney convoluted tubules were observed with thickened basement membrane, disorganization of interdigitations, and significant decrease of their number; in some areas was noted swelling of rough endoplasmic reticulum (RER) and mitochondrial cristae (Figure 4A). As it is seen in Figure 4A, the capillary endothelial cell cytoplasm also presented swollen RER and mitochondria. Spleen ultrastructure was studied in T. evansi-infected mice. Tissular disorganization, fibrosis, and apoptotic bodies (Figure 4B), as well as necrosis were observed. The inflammatory infiltrate consisted of mononuclear cells, such as neutrophils, eosinophils, and macrophages (Figures 1B and 5A,B). Trypanosomatids were found in extracellular spaces and inside of mononuclear cells (Figures 1B and 5A,B).

\section{DISCUSSION}

Infection with several trypanosomatids leads to a rapidly lethal disease in different strains of mice. According to various authors [for review Ref. (13)], living and dead trypanosomes produce a number of biologically active substances, which are involved in the etiology of lesion. As it has been shown in mice infected with T. cruzi, the acute infection is characterized by a severe immune depression (14). Immunosuppresion also occurs in Leishmaniasis (15). The mechanism of action of released molecules by $T$. cruzi and Leishmania sp. could suggest a role as regulatory activating and inhibiting factors of host immune cells $(14,16,17)$. The role of IFN- $\gamma$ during T. cruzi infection was demonstrated when IFN- $\alpha$ and IFN- $\gamma$ receptor KO mice showed higher rates of parasitemia and mortality (18). Infected IFN- $\gamma$ KO mice showed increase in cellular infiltrates in heart and skeletal muscles and reduced survival (18-20).

A number of reports have documented the role of $\mathrm{NO}$ in host defense against pathogens. In the case of T. cruzi, experimental infection induces NO production and suggests that IFN- $\gamma$ and TNF- $\alpha$ are involved in the phenomenon $(21,22)$. Recently, it was reported that in L. amazonensis infected mice, pravastatin increased the phagocytosis mediated by complement and immunoglobulin receptors, and induced a rise of nitric oxide production by macrophages, allowing these cells to kill ingested leishmania organisms, with reduction of the overproduction of tumor necrosis factor (23). Other experiments have shown that IFN- $\gamma$ and TNF- $\alpha$-mediated activation of macrophages leads to increased production of $\mathrm{NO}$, which in turn suppresses $\mathrm{T}$ cell activation. $\mathrm{NO}$ and oxygen radicals release from locally activated macrophages and stimulated endothelial or tissue cells, have been implicated as the final mediators in cytokine-induced pathology in malaria $(24,25)$.

Our investigation in murine experimental infection with trypanosomatids is in line with a degree of striated muscle alterations, which varied from slight to severe, during the pathogenesis and development of disease. The ultrastructural pathology data are similar to previous results concerning cardiac myocytes in hamsters and mice experimentally infected with T. cruzi $(6,26)$, "derrengadera" by T. evansi in wild horse skeletal muscle fibers (1), and in mice parasitized with T. gondii (3). In advanced Chagas' 


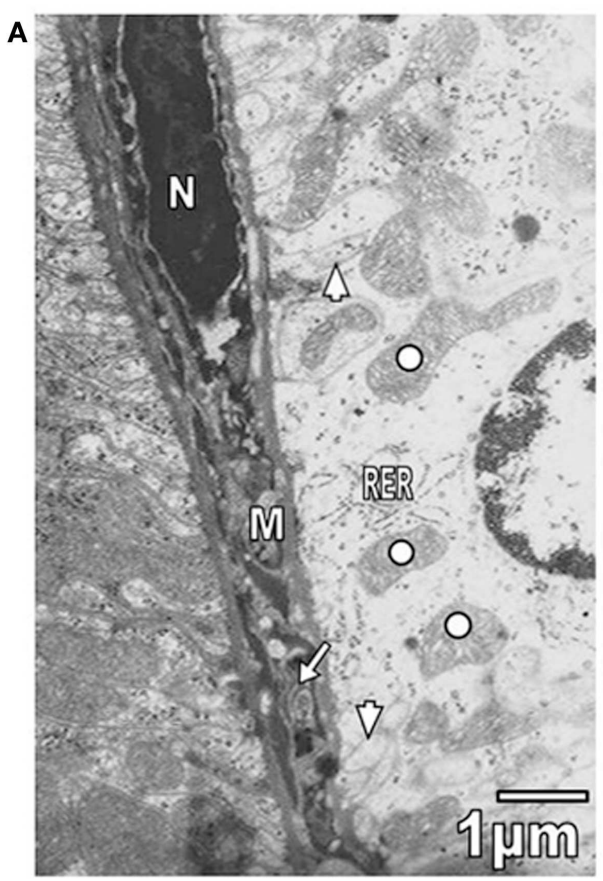

FIGURE 4 | (A) Section from proximal convolute tubule of a mouse parasitized by $T$. evansi is shown. Observe portions of interdigitations (arrowheads), swelling of RER cisternae, and mitochondrial cristae (open circle). In the

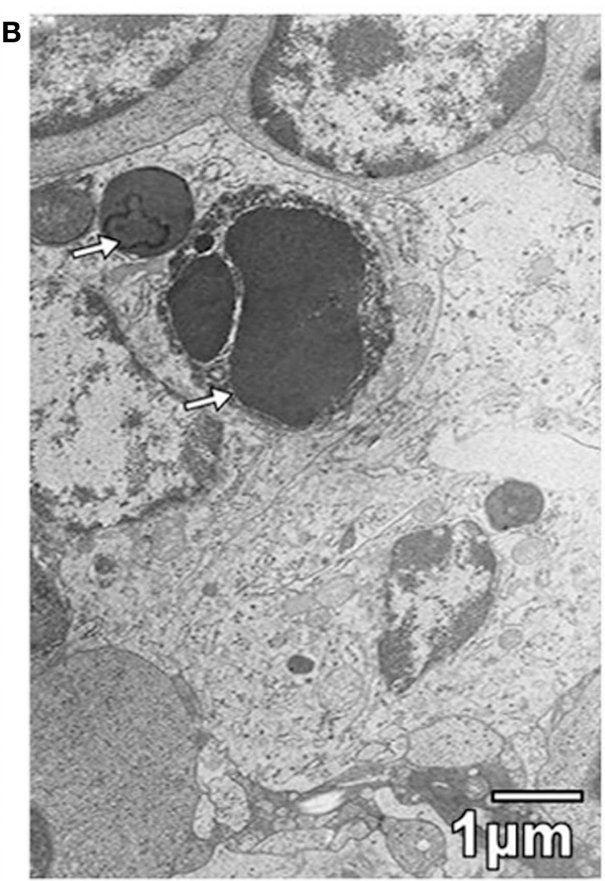

capillary, swollen RER (arrow), mitochondria (M), and hyperchromatic nucleus (N) are seen. (B) Section of spleen from parasitized mouse with T. evansi is shown. Note the presence of apoptotic bodies (arrows).
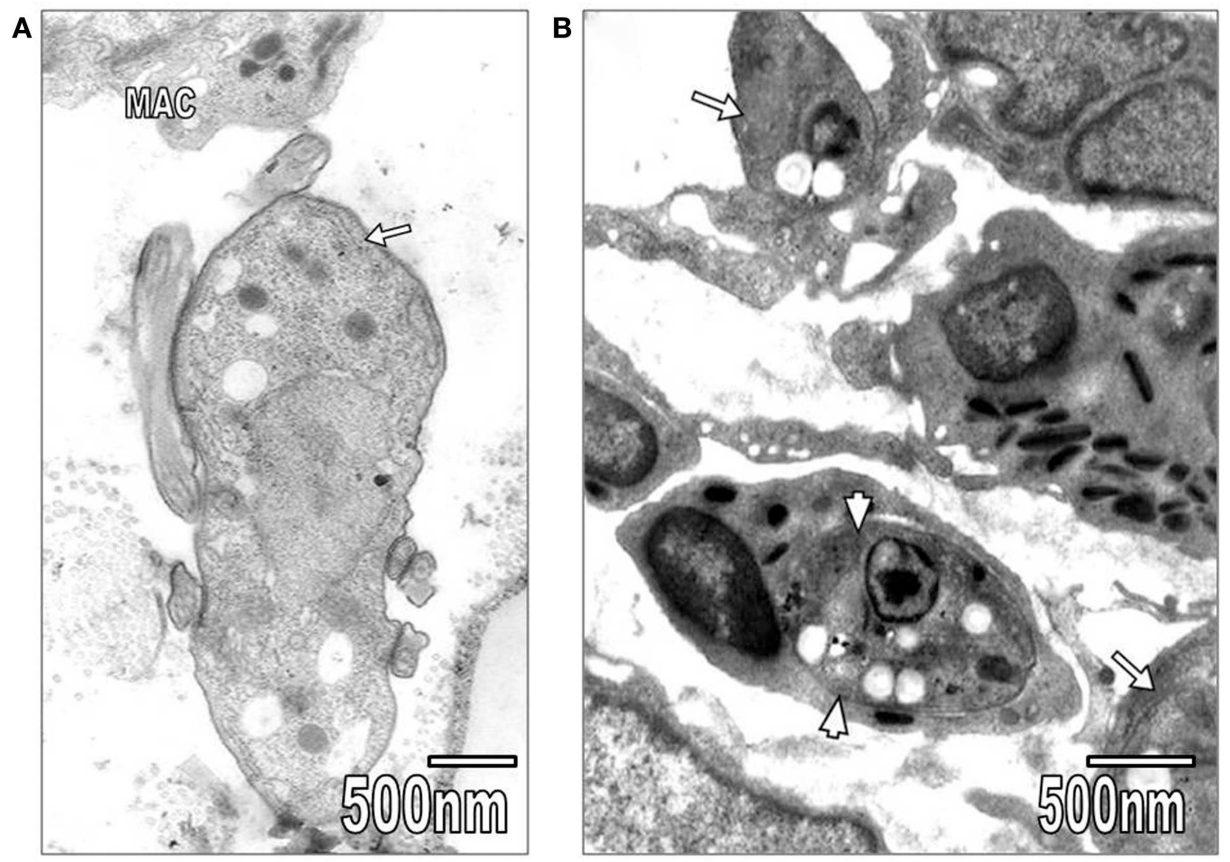

FIGURE 5 | (A) In this section, T. evansi (arrow) and a macrophage (MAC) are seen. (B) Section showing L. mexicana organisms inside of an eosinophil (arrowheads) and a macrophage (arrows). 
disease patients, capillary damage also has been reported in skeletal muscle (5).

These results in relation to changes in liver hepatocytes of mice infected by T. cruzi and T. evansi were in some aspects similar to those described in liver of mice parasitized with P. berghei (27), including an increment of lipid droplets and depletion of glycogen particles, simultaneously with a decrease of microvilli in the Disse's space. Also, necrotic hepatocytes and a thickening of endothelial cell cytoplasm were found in both cases. In adrenal cortex of mice infected with P. berghei (11), erythrocytes were observed inside cortical cell cytoplasm, as we also observed in the infection with T. cruzi and the report by Rodríguez-Acosta et al. (28) in cortex of adrenal gland in mice injected with a lethal dose fifty $\left(\mathrm{LD}_{50}\right)$ of bee venom. In the investigation of Pulido-Méndez et al. (11), parasites were not seen inside of cortical cells. On the contrary, in T. evansi infected cortical cells contained trypanosomes as it was described by Rossi et al. (9), and in the present work.

The ultrastructural pathological changes as those described in hepatocytes and adrenal cortical cells also were found in kidney of mice in Plasmodium berghei infection (12), including swelling of some organelles and disorganization of interdigitations and decrease of their number in some areas. Interestingly, loss of interdigitations and tubular vacuolization were also described in convoluted proximal tubules of mice intraperitoneally injected with a lethal dose fifty $\mathrm{LD}_{50}$ of Apis mellifera (29) in association with swelling of endothelial cell mitochondria and RER as in the present work.

Besides the splenic changes caused by action of parasite could be related to a possible capability for particular proteolytic secretions (9), due to a T. evansi induced hepatic alteration since a liver deterioration can rise the portal pressure. Indeed, advanced hepatomegaly increases the portal flux causing the blood to flow through collateral systems via portal and cava veins (30). The portal flux increments are determined by vasodilatation of the splanchnic tissue (stomach, intestine, pancreas, and spleen) admitting consequently an augmentation in the blood flux arriving to the organs (31). The first ultrastructural indication of damage is through a considerable amount of splenic debris. According to Jain (32), the presence of such remains is derived from erythrophagocytosis and cell debris phagocytosis occurring in the infected spleen.

The mononuclear cell infiltrate consisted of neutrophils, eosinophils, and macrophages. Macrophages and eosinophils were reported by Tonino et al. (3) in mice infected by $T$. gondii. Similarly, macrophages were reported by Quiñones Mateu et al. (1) in horses parasitized by $T$. evansi and in mice infected by $P$. berghei (12). In our investigation, we did not observe mastocytes as described in the infection with T. gondii (3) and lymphocytes as reported in mice infected by $P$. berghei (12). Our ultrastructural study demonstrates that several tissues of mice are certainly targets for trypanosomatids. Moreover, the murine model is very useful for pathological studies in trypanosomiasis using transmission electron microscopy.

\section{REFERENCES}

1. Quiñones Mateus ME, Finol HJ, Sucre LE, Torres SH. Muscular changes in Venezuelan wild horses naturally infected with Trypanosoma evansi. J Comp Pathol (1994) 110(1):79-89. doi:10.1016/S0021-9975(08)80272-1
2. Finol HJ, Boada-Sucre A, Rossi M, Tejero F. Skeletal muscle ultrastructural pathology in mice infected with Trypanosoma evansi. J Submicrosc Cytol Pathol (2001) 33(1-2):65-71.

3. Tonino P, Finol HJ, Márquez A. Skeletal muscle pathology in mice experimentally infected with Toxoplasma gondii. J Submicrosc Cytol Pathol (1996) 28(4):521-6.

4. Bruzual E, Finol HJ, Arcay L. Anormalidades ultraestructurales de la musculatura esquelética en ratones infectados con Toxoplasma gondii y tratados con ciclofosfamida. Rev Sci (2002) XII(1):19-23.

5. Torres SH, Finol HJ, Montes de Oca M, Vásquez F, Puigbó JJ, Loyo JG. Capillary damage in skeletal muscle in advanced Chagas' disease patients. Parasitol Res (2004) 93(5):364-8. doi:10.1007/s00436-004-1107-7

6. Pereira MCS, Costa M, Chagas Filho C, De Meirelles MNL. Myofibrillar breakdown and cytoskeletal alterations in heart muscle cells during invasion by Trypanosoma cruzi: immunological and ultrastructural study. J Submicrosc Cytol Pathol (1993) 25(4):559-69.

7. Carmona M, Finol HJ, Márquez A, Noya O. Skeletal muscle ultrastructural pathology in Serinus canarius infected with Plasmodium cathemerium. J Submicrosc Cytol Pathol (1996) 28(1):87-91.

8. Davies TME, Pongponratan E, Supanaranond W, Pukrittayakamee S, Helliwell T, Holloway P, et al. Skeletal muscle involvement in falciparum malaria: biochemical and ultrastructural study. Clin Infect Dis (1999) 29(4):831-5. doi:10.1086/520444

9. Rossi M, Boada-Sucre A, Finol HJ, Tejero F, Bello B, Aso PM, et al. Ultrastructural alterations in the adrenal gland cortex of mice experimentally infected with a venezuelan isolate of Trypanosoma evansi. J Submicrosc Cytol Pathol (1999) 31(4):509-13.

10. Rossi MS, Boada-Sucre A, Hernández G, Bello B, Finol HJ, Payares-Trujillo G, et al. Análisis ultraestructural del hígado en ratones infectados experimentalmente con un aislado venezolano del Trypanosoma evansi (Kinetoplastida: Trypanosomatidae). Acta Microsc (2008) 17(2):5-12.

11. Pulido-Méndez M, Finol HJ, Márquez A, Aguilar I, Girón ME, González N, et al. Adrenal cortex alterations in mice infected with Plasmodium berghei. J Submicrosc Cytol Pathol (1997) 29(1):99-104.

12. Pulido-Méndez M, Finol HJ, Márquez A, Girón ME, Aguilar I, Rodríguez-Acosta A. Ultrastructural pathological changes in mice kidney caused by Plasmodium berghei infection. J Submicrosc Cytol Pathol (2006) 38(2-3):143-8.

13. Igbokwe IO. Mechanisms of cellular injury in African trypanosomiasis. Vet Bull (1994) 64(7):611-20.

14. Ouaissi A, Cordeiro Da Silva AC, Guevara AG, Borges M, Guilvard E. Trypanosoma cruzi-induced host immune system dysfunction: a rationale for parasite immunosuppressive factor(s) encoding gene targeting. J Biomed Biotechnol (2001) 1(1):11-7. doi:10.1155/S1110724301000055

15. Carvalho EM, Bacellar O, Barral A, Badaro R, Johnson WD Jr. Antigen-specific immunosuppression in visceral leishmaniasis is cell mediated. J Clin Invest (1989) 83(3):860-4. doi:10.1172/JCI113969

16. Cordeiro-da-Silva A, Borges MC, Guilvard E, Ouaissi A. Dual role of the Leishmania major ribosomal protein S3a homologue in regulation of T- and B-cell activation. Infect Immun (2001) 69(11):6588-96. doi:10.1128/IAI.69.11.65886596.2001

17. Ouaissi A, Guilvard E, Delneste Y, Caron G, Magistrelli G, Herbault N, et al. The Trypanosoma cruzi Tc52-released protein induces human dendritic cell maturation, signals via toll-like receptor 2 , and confers protection against lethal infection. J Immunol (2002) 168(12):6366-74. doi:10.4049/jimmunol.168.12.6366

18. Hölscher C, Köhler G, Müller U, Mossmann H, Schaub GA, Brombacher F. Defective nitric oxide effector functions lead to extreme susceptibility of Trypanosoma cruz-induced mice deficient in gamma interferon receptor or inducible nitric oxide synthase. Infect Immun (1998) 66(3):1208-15.

19. Marinho CRF, Nuñez-Apaza LN, Martins-Santos R, Bastos KRB, Bombeiro AL Bucci DZ, et al. IFN- $\gamma$, but not nitric oxide or specific IgG, is essential for the in vivo control of low-virulence Sylvio X10/4 Trypanosoma cruzi parasites. Scand J Immunol (2007) 66(2-3):297-308. doi:10.1111/j.1365-3083.2007.01958.x

20. Michailowsky V, Silva NM, Rocha CD, Vieira LQ, Lannes-Vieira J, Gazzinelli RT. Pivotal role of interleukin-12 and interferon- $\gamma$ axis in controlling tissue parasitism and inflammation in the heart and central nervous system during Trypanosoma cruzi infection. Am J Pathol (2001) 159(5):1723-33. doi:10.1016/S0002-9440(10)63019-2

21. Muñoz-Fernández MA, Fernández MA, Fresno M. Activation of human macrophages for the killing of intracellular Trypanosoma cruzi by TNF- $\alpha$ and IFN- $\gamma$ through a nitric oxide-dependent mechanism. Immunol lett (1992) 33(1):35-40. doi:10.1016/0165-2478(92)90090-B 
22. Petray P, Rottemberg ME, Grinstein S, Örn A. Release of nitric oxide during the experimental infection with Trypanosoma cruzi. Parasite Immunol (1994) 16(4):193-9. doi:10.1111/j.1365-3024.1994.tb00340.x

23. Kückelhaus CS, Kückelhaus SAS, Tosta CE, Muniz-Junqueira MI. Pravastatin modulates macrophage functions of Leishmania (L.) amazonensis-infected BALB/c mice. Exp Parasitol (2013) 134(1):18-25. doi:10.1016/j.exppara.2013. 01.020

24. Clark IA, Rockett KA, Cowden WB. Proposed link between cytokines, nitric oxide and human cerebral malaria. Parasitol Today (1991) 7(8):205-7. doi:10. 1016/0169-4758(91)90142-B

25. Mendis KN, Carter R. Meeting report: clinical disease and pathogens in malaria. Parasitol Today (1995) 11(5):TI2-16. doi:10.1016/0169-4758(95)80143-X

26. Colmanetti FH, Antunes Teixeira VP, Pinto Rodrigues MA, Lazo Chica JM, das Gracas Reis M. Myocardiocyte ultrastructure and morphometrical analysis in hamsters experimentally infected with Trypanosoma cruzi. Ultrastruct Pathol (2005) 29(2):139-47. doi:10.1080/019131290923974

27. Rodríguez-Acosta A, Finol HJ, Pulido-Méndez M, Márquez A, Andrade G, González N, et al. Liver ultrastructural pathology in mice infected with Plasmodium berghei. J Submicrosc Cytol Pathol (1998) 30(2):299-307.

28. Rodríguez-Acosta A, Vega J, Finol HJ, Pulido-Méndez M. Ultrastructural alterations in cortex of adrenal gland caused by the toxic effect of bee (Apis mellifera) venom. J Submicrosc Cytol Pathol (2003) 35(3):309-14.

29. Rojas G, Rodríguez-Acosta A, Finol HJ, Céspedes G, Hernández A. Daños estructurales y ultraestructurales en riñón, músculo y vasos de ratón producidos por la agresión tóxica del veneno de abeja (Apis mellifera). Rev Sci (2002) XII(1):46-52.
30. Galindo B. Ultraestructura de la pulpa blanca del bazo de ratón. Ph.D Thesis. Faculty of Medicine, Central University of Venezuela (1962).

31. Magaloti D, Marchesini G, Ramilli S, Berzigotti A, Biachi G, Zoli M. Splanchnic haemodynamics in non-alcoholic fatty liver disease: effect of a dietary/pharmacological treatment. A pilot study. Digest liver Dis (2004) 36(6):406-11. doi:10.1016/j.dld.2004.01.023

32. Jain NC. Essentials of Veterinary Hematology. Philadelphia: Lea and Fabinger (1993). 417 p.

Conflict of Interest Statement: The authors declare that the research was conducted in the absence of any commercial or financial relationships that could be construed as a potential conflict of interest.

Received: 21 May 2014; accepted: 25 June 2014; published online: 08 July 2014.

Citation: Finol HJ and Roschman-González A (2014) Ultrastructural study on tissue alterations caused by trypanosomatids in experimental murine infections. Front. Public Health 2:75. doi: 10.3389/fpubh.2014.00075

This article was submitted to Epidemiology, a section of the journal Frontiers in Public Health.

Copyright (C) 2014 Finol and Roschman-González. This is an open-access article distributed under the terms of the Creative Commons Attribution License (CC BY). The use, distribution or reproduction in other forums is permitted, provided the original author(s) or licensor are credited and that the original publication in this journal is cited, in accordance with accepted academic practice. No use, distribution or reproduction is permitted which does not comply with these terms. 